\title{
Upaya Meningkatkan Motivasi dan Hasil Belajar Melalui Problem Based Learning dengan Powerpoint di Sekolah Dasar
}

\author{
Suwartini \\ Universitas Veteran Bangun Nusantara \\ tinuth28@gmail.com
}

\begin{abstract}
Abstrak
Penelitian ini bertujuan untuk meningkatkan motivasi dan hasil belajar belajar kelas IV Sekolah Dasar Negeri Kenokorejo 01. Penelitian ini merupakan penelitian tindakan kelas. Subjek penelitian adalah siswa kelas IV.Pengumpulan data menggunakan teknik dokumentasi, observasi, angket dan tes. Validitas data menggunakan teknik triangulasi sumber dan triangulasi metode. Teknik analisis data kualitatif menggunakan model interaktif yaitu reduksi data, penyajian data, dan penarikan kesimpulan. Sedangkan data kuantitatif dianalisis secara deskripif. Hasil penelitian sebagai berikut: (1) Motivasi belajar siswa yang berkategori "tinggi" dari pada yang siklus I sebesar $41 \%$ atau 4 siswa dan pada kategori sedang $58 \%$ atau 7 siswa. Pada siklus II kategori tinggi menjadi $83 \%$ atau 10 siswa dan kategori sedang $17 \%$ atau 2 siswa. 2) Hasil belajar siswa sebelum tindakan hanya mencapai $28 \%$ atau 3 siswa yang tuntas. Setelah tindakan pada siklus I, sebanyak 7 siswa atau sebesar $64 \%$ telah tuntas. Siklus II 11 siswa atau sebesar $91 \%$ telah tuntas.
\end{abstract}

Kata kunci: motivasi, hasil belajar, problem based learning, powerpoint

\begin{abstract}
The purpose of this research was to enhance motivation and science learning outcomes of grade IV students at elementary school Negeri Kenokorejo 01. This research is a classroom action research. The subjects of this research was the students of grade IV SDN Kenkokorejo 01. Data collection uses documentation,observation, questionnaire and test techniques. The data validity was using source triangulation technique and method triangulation. The qualitative data analysis technique uses an interactive model,namely data reduction, data presentation, and drawing conclusions. While quantitative data were analyzed descriptively. The results showed the following: (1) The learning motivation of students who are categorized as "high" in the first cycle is 58\% or 7 students. In the second cycle to $83 \%$ or 10 students. 2) Student learning outcomes before the action only reached $28 \%$ or 3 students who completed. After the action in the first cycle, as many as 7 students or $64 \%$ have completed. Cycle II 11 students or $91 \%$ completed.
\end{abstract}

Keywords: learning motivation, learning outcomes, problem based learning, powerpoint

https://doi.org/. 


\section{PENDAHULUAN}

Pembelajaran daring perlu dilakukan dimasa pandemi seperti ini guna memutus rantai pencegahan Covid-19. Dengan merujuk PP Nomor 21 Tahun 2020 Pembatasan Sosial Besar Dalam Rangka Percepatan Penanganan Corona Virus Disease 2019 (Covid19), dengan demikian pembelajaran pada satuan pendidikan yang dulu secara luring tatap muka sekarang berubah menjadi system daring. Melalui pembelajaran daring peserta didik akan tetap mendapatkan haknya untuk memperoleh pembelajaran. Namun, dalam pembelajaran daring kurang dapat berjalan dengan lancar. Dikarenakan tidak sedikit biaya yang dikeluarkan mengikuti pembelajaran secara daring.

Pembelajaran daring guru dituntut memberikan pengajaran yang baik sehingga menciptakan suasana pembelajaran yang kondusif untuk belajar dan secara kreatif dan inovatif untuk meningkatkan motivasi belajar siswa. Selain itu, terjadinya perubahan dalam proses pembelajaran juga berpengaruh pada siswa terhadap motivasi belajarnya.

Berdasarkan hasil observasi pembelajaran secara daring pada muatan pelajaran Ilmu Pengetahuan Alam di kelas IV SD Negeri Kenokorejo 01 pada semester II tahun pelajaran 2020/2021 yang berjumlah 12 siswa yang terdiri dari 5 siswa perempuan dan 7 sisswa laki-laki, motivasi belajar siswa dalam mengikuti pembelajaran IPA masih rendah. Dengan rendahnya morivasi belajar siswa menyebabkan hasil belajar siswa juga menjadi rendah. Berdasarkan hasil penilaian harian dari 12 siswa terdapat 8 siswa dengan persentase 73\% yang masihmemiliki nilai dibawah KKM yang ditetapkan yaitu 67 dan yang tuntas KKM hanya 3 siswadengan persentase 27\%. Kondisi yang diharapkan bahwa siswa kelas IV memiliki motivasiberkategori tinggi dengan nilai motivasi belajar siswa minimal 70 sehingga berpengaruh pada pencapaian hasil belajar IPA diatas KKM yaitu 70.

Menurut Maryam Muhammad (2016:1) Motivasi adalah perubahan tenaga di dalam diri seseorang yang ditandai dengan dorongan yang berasal dari diri seseorang untuk mencapai tujuan. Suttrisno (2020:720) dalam penelitiannya menambahkan bahwa motivasi dan hasil belajar siswa dapat ditingkatkan melalui banyak cari misalnya penggunaan alat peraga, media maupun model bealajar yang disesuaikan dengan kondisi di dalam kelas dan juga siswanya.

Adanya kesenjangan antara harapan dengan kenyataan, maka peneliti memberi solusi atas permasalahan tersebut dengan Model pembelajaran yang dapat melatih siswa untuk berpikirr kritis dalam memecahkan masalah yakni dengan model pembelajaran Problem Based Learning. Menurut (Siswono, 2005) (Asrani Assegaff: 2016) Problem Based Learning adalah suatu pendekatan pembelajaran yang dimulai dengan mengajukan masalah dan dilanjutkan dengan menyelesaikan masalah tersebut. Serta menggunakan media powerpoint untuk meningkatkanmotivasi dan hasil belajar siswa. Menurut Erhans (2011; 7) media powerpoint memudahkan kita dalam merancang berbagai bahan presentasi visual yang menakjubkan menggunakan teks, grafis, foto, animasi, video dan kuis dalam penyajian persentasi kepada siswa. Dengan penyajian materi ajar IPA menggunakan media powerpoint di SD Negeri Kenokrejo 01, diharapkan dapat menarik perhatian siswa sehingga siswa senang dalam mengikuti kegiatan pembelajaran, hasil belajar meningkat dan pembelajaran dapat bersifatdua arah.

Hal tersebut didukung oleh penelitian Mutmainah (2018) mengenai penggunaan media powerpoint motivasi dan hasil belajar siswa dalam pembelajaran IPS dengan materikenampakan alam meningkat dari siklus I sampai siklus ke III. Strategi atau model pembelajaran perlu digunakan dalam proses pembelajaran guna menciptakan kondisi pembelajaran yang dan melatih siswa untuk berpikir kritis dalam memecahkan masalah.

Berdasarkan uraian di atas, maka dapat dirumuskan tujuan penelitian ini adalah dengan menerapkan model pembelajaran Problem Based Learning dengan media 
powerpoint untuk meningkatkan motivasi dan hasil belajar siswa kelas IV SD Negeri Kenokorejo 01 tahun pelajaran 2020/2021.

\section{METODE PENELITIAN}

Jenis penelitian ini adalah ini adalah penelitian tindakan kelas (PTK) yang dilakukan pada kelas IV SD Negeri Kenokorejo 01 pada semester II tahun pelajaran 2020/2021. Penelitian tindakan kelas bermula dari masalah riil dalam proses belajar mengajar di kelas, kemudian diangkat dan dijadikan sebuah permasalahan yang memerlukan alternatif pemecahan masalahnya.

Teknik pengumpulan data yang digunakan adalah: (a) angket (b) observasi (c) tes (d) dokumentasi. Dalam penelitian ini angket digunakan untuk mengumpulkan informasi terkait motivasi belajar siswa setelah tindakan. Observasi dilakukan untuk mengamati aktivitas guru dan siswa untuk mengevaluasi setiap tindakan untuk meningkatkan proses pembelajaran dengan instrumen lembar observasi. Tes hasil belajar digunakan untuk mengukur pengetahuan siswa terhadap materi pembelajaran yaitu muatan pelajaran IPA pada setiap pertemuan. Dokumentasi dilaksanakan guna memperkuat data setelah observasi dan mengumpulkan informasi terkait data sekolah seperti: profil sekolah, daftarnama siswa, dan hasil belajar siswa.

Teknik analisis data menggunakan teknik analisis model interaktif yang dikembangkan oleh Huberman (dalam Yanto 2013:68) terdiri atas tiga komponen yaitu reduksi data, beberan (dislay) data, dan penarikan kesimpulan. Analisis data kuantitatif dilakukan secara deskriptif.

Dalam penelitian ini juga menggunakan validitas data untuk menguji keabsahan data. Validitas data menggunakan triangulasi sumber dan triangulasi teknik, validitas data ini digunakan untuk menjamin hasil informasi yang akurat dan menjamin validitas data, agar tidak salah dalam pengambilan keputusan. Menurut Sugiyono (2012:327) Triangulasi sumber, triangulasi sumber digunakan untuk mendapatkan data dari sumber yang berbeda dengan teknik yang sama dan triangulasi teknik, triangulasi teknik merupakan teknik pengumpulan data yang berbeda-beda untuk mendapatkan data dari sumber yang sama.

Indikator keberhasilan kinerja dalam penelitian ini yakni pencapaian keaktifan belajar siswa dalam setiap aspek, diantaranya: motivasi belajar $80 \%$ atau sekitar 10 siswa dalam kategori tinggi dan tercapainya indikator hasil belajar dengan ketuntasan belajar mencapai 80\% dari 12 atau 10 siswa yang mendapatkan $\geq$ nilai KKM. Dimana KKM pada muata pelajaran IPA yakni 70.

\section{HASIL DAN PEMBAHASAN}

Pembelajaran kelas IV di SD Negeri Kenokorejo 01 ditemukan permasalahan yaitu penggunaan media pembelajaran daring kurang maksimal. Hal tersebut menyebabkan motivasi belajar siswa rendah. Ditunjukkan dengan siswa tidak memperhatikan penjelasanguru, asik berbicara dengan teman, siswa kurang mempunyai rasa ingin tahu yang mendalam terhadap materi, kurang antusias saat menjawab pertanyaan atau bertanya dan siswa mengumpulkan tugas tidak tepat waktu.

Motivasi belajar tersebut berpengaruh terhadap hasil belajar muatan pelajaran IPA siswa kelas IV SD Negeri Kenokorejo 01. Diperoleh data awal bahwa sebanyak 3 siswa (28\%) sedangkan siswa yang belum mencapai ketuntasan belajar sebanyak 8 siswa (72\%).Dalam pembelajaran IPA menurut Marjono (dalam Susanto, 2013:167) hal yang harus diutamakan adalah bagaimaa mengembangkan rasa ingin tahu dan daya berpikir kritis mereka tehadap suatu masalah. Para guru harus melaksanakan Jurnal Riset Madrasah Ibtidaiyah (JURMIA). Vol. 1, No.1 
pembelajaran secara aktif dan kreatif dalam melibatkan siswa serta menggunakan berbagai strategi dan media pembelajaran yang bervariasi.

Dilihat dari permasalahan tersebut maka memberikan solusi untuk meningkatkan motivasi dan hasil belajar dengan menggunakan model pembelajaran Problem Based Learning dengan media powerpoint.

Penelitian ini dilaksanakan dalam dua siklus masing-masing dua pertemuan setiap siklusnya. Setiap pertemuan dengan alokasi waktu 2x35 menit (2 JP). Pada siklus I perencanaan yang dilakukan antara lain: menelaah silabus kelas IV, menyusun Rencana Pelaksanaan Pembelajaran (RPP), menyusun perangkat pembelajaran, membuat media powerpoint, membuat lembar observasi guru dan siswa, membuat lembar angket motivasi belajar siswa, serta mempersiapkan fasilitas dan sarana pendukung.

Setelah diadakannya tindakan siklus I diperoleh hasil motivasi dan hasil belajar siswa yang meningkat daripada sebelum tindakan. Seiring dengan meningkatnya motivasisiswa berpengaruh pula terhadap hasil belajar siswa. Seperti yang diungkapkan Rusman (2015) motivasi belajar yang besar cenderung menghasilkan prestasi yang tinggi, sebaliknya motivasi belajar kurang akan menghasilkan prestasi yang rendah.

Persentase motivasi belajar siswa yang berkategori tinggi pada siklus I sebesar 58\%atau 7 siswa dan siswa yang dikategorikan sedang 41\% atau 5 siswa. Hal tersebut menunjukkan kenaikan yang cukup signifikan. Dengan naiknya motivasi belajar siswa makan hasil belajar siswa pada siklus I juga menunjukkan kenaikan yakni 7 siswa atau 64\% mendapatkan nilai lebih dari KKM.

Menurut Ratna (2013) siswa mampu menguasai materi yang diajarkan jika dalam diri memiliki motivasi yang kuat. Selain itu, motivasi juga mampu memberikan doronganuntuk bertindak sesuai tujuan yang diinginkan, sehingga aktivitas menjadi bagian yang sangat penting dalam motivasi (Lee \& Martin: 2017). Antusias siswa sudah nampak untukmengikiti proses pembelajaran dengan penggunaan model pembelajaran problem based learning dan media powerpoint. Penelitian dilanjutkan di siklus II dengan mengatasi kekurangan yang ada di siklus I. Pada pelaksanaan siklus II media yang dibuat lebih simpel dengan menampilkan teks, beberapa gambar, video, dan animasi sehingga mudah dipahami. Siswa lebih antusias padakegiatan pembelajaran terlihat dalam menyampaikan pertanyaan, pendapat maupun ide. Guru telah berusaha menciptakan suasana belajar yang santai, menyenangkan, dan terkendali. Proses pembelajaran pada siklus II lebih meningkatkan pemahaman siswa terhadap materi pembelajaran.

Peningkatan motivasi siswa sudah nampak dengan tercapainya indikator keberhasilan penelitian, ditunjukkan dengan siswa yang berkategori "tinggi" sudah nampak pada pelaksanaan siklus II. Siswa yang berkategori "tinggi” mencapai 83\% atau 10 siswa; dan berkategori "rendah" atau "sedang" sebanyak 2 siswa atau sebesar 17\%. Setelah dilakuakannya evaluasi pada siklus II persentase jumlah siswa yang tuntas KKM sudah meningkat. Sebanyak 1 siswa atau sebesar 9\% belum mencapai ketuntasan belajar,sedangkan 10 siswa atau sebesar 91\% telah tuntas KKM yaitu 70 .

Dengan begitu indikator penelitian sudah terpenuhi pada pelaksanaan siklus II. Namun masih terdapat 1 siswa dengan motivasi belajar berkategori sedang dan hasil belajar yang belum tuntas KKM dikarenakan siswa tersebut lebih banyak diam dalam kegiatan pembelajaran, kurang fokus saat guru menjelaskan sehingga daya serap akan materi masih kurang.

Adapun peningkatan ketuntasan motivasi belajar siswa kelas IV SD Negeri Kenokorejo 01 dari siklus I, hingga siklus II seperti pada tabel berikut:

\section{Tabel 1. Persentase Motivasi Belajar}




\begin{tabular}{|cccccc|}
\hline \multirow{2}{*}{ Interval } & \multirow{2}{*}{ Skor } & \multicolumn{2}{c}{ Siklus I } & \multicolumn{2}{c|}{ Siklus II } \\
\cline { 3 - 6 } & & Frekuensi & Persentase & Frekuensi & Persentase \\
\hline $\mathbf{0 - 3 9}$ & Rendah & 0 & $0 \%$ & 0 & $0 \%$ \\
$\mathbf{4 0 - 6 9}$ & Sedang & 5 & $41 \%$ & 2 & $17 \%$ \\
$\mathbf{7 0 - 1 0 0}$ & Tinggi & 7 & $58 \%$ & 10 & $83 \%$ \\
\hline
\end{tabular}
berikut:

Peningkatan ketuntasan motivasi belajar siklus I ke siklus II disajikan pada grafik

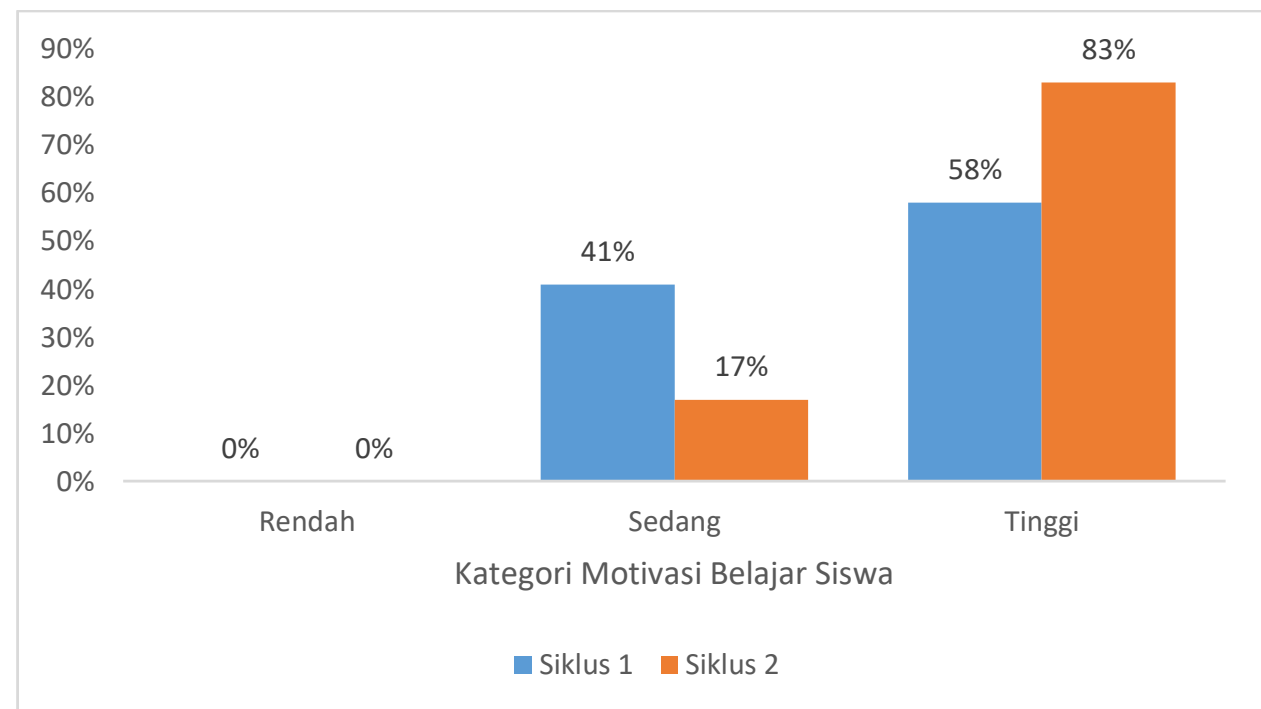

\section{Gambar 1. Ketuntasan Motivasi belajar}

Adapun peningkatan ketuntasan hasil belajar siswa dari pra siklus sampai tindakansiklus II seperti pada tabel berikut:

Tabel 2. Persentase Hasil Belajar Siswa Kelas IV

\begin{tabular}{cccc}
\hline Aspek yang diamati & Sebelum & Siklus I & Siklus II \\
& Tindakan & & \\
\hline Jumlah siswa / persentase & 3 siswa / & 7 siswa / & 11 siswa / \\
yang telah mencapai KKM & $28 \%$ & $58 \%$ & 91 \\
& & & $\%$ \\
\hline
\end{tabular}

Peningkatan persentase hasil belajar dari pra siklus, siklus I ke siklus II setelah menggunakan model pembelajaran problem based learning dengan media powerpoint disajikan pada grafik berikut: 


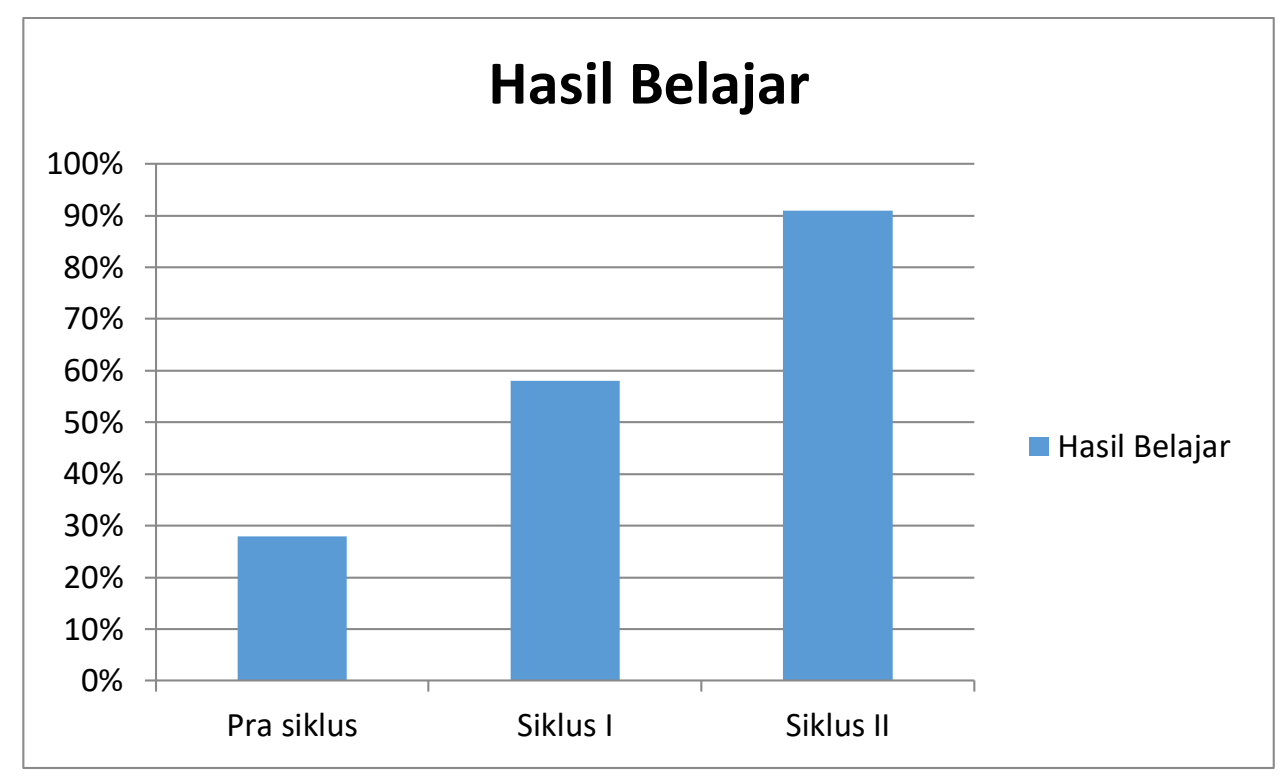

Gambar 2. Hasil Belajar Siswa

Penelitian ini mendukung penelitian sebelumnya yang dilakukan oleh Lari (2014) menyimpulkan bahwa sebagian besar siswa menunjukkan persepsi positif terhadap penggunaan media powerpoint di kelas Bahasa Inggris. Dalam penelitian ini media powerpoint beroperasi sebagai alat pedagogis yang baik sehingga mendukung keunggulan pelajaran berbasis teknologi dengan mempertimbangkan minat siswa.

Berdasarkan hasil penelitian dengan menggunakan model pembelajaran Problem Based Learning dengan media powerpoin dapat mengatasi permasalahan yang terjadi pada siswa kelas IV SD Negeri Kenokorejo 01 tahun pelajaran 2020/2021. Penelitian ini masih ada 1 siswa yang belum mencapai indikator pencapaian, hal ini dikarenakan siswa yang bersangkutan saat pembelajaran kurang fokus dan ketika mengerjakan soal evaluasi ada soal yang panjang siswa tersebut malas untuk membacanya, dan langsung memilih jawaban. Dari permasalahan siswa yang belum tuntas mendapat nilai $\geq K K M$, guru memberikan motivasi secara personal kepada siswa untuk lebih senang dalam membaca, serta memberikan motivasi untuk fokus dalam proses pembelajaran agar dapat menyerap materi pembelajaran dan mendapatkan nilai $\geq \mathrm{KKM}$.

\section{KESIMPULAN DAN SARAN}

Berdasarkan hasil penelitian tindakan kelas yang telah dilakukan, maka dapat disimpulkan bahwa penggunaan model pembelajaran Problem Based Learning dengan media powerpoint dapat meningkatkan motivasi belajar dan hasil belajar siswa kelas IV Sekolah Dasar Negeri Kenokorejo 01 tahun pelajaran 2020/2021. Dibuktikan dengan adanya peningkatan pada setiap siklusnya, sebagai berikut, motivasi belajar siswa kelas IV SD Negeri Kenokorejo 01 meningkat dari siklus I terdapat 6 siswa yang memiliki kategori tinggi, dan pada siklus II terdapat 10 siswa yang memiliki kategori tinggi. Serta hasil belajar IPA siswa kelas IV SD Negeri Kenokorejo 01 meningkat dari pra siklus 3 siswa (28\%) yang mendapat nilai $\geq \mathrm{KKM}$, pada siklus I 7 siswa (58\%) yang mendapat nilai $\geq$ KKM, kemudian pada siklus II 11 siswa (91\%) yang mendapat nilai $\geq K K M$.

Adapun saran berdasarkan hasil penelitian yang telah dilakukan, dan keterbatasan penelitian dengan model problem based learning dan media powerpoint dapat digunakan sebagai salah satu alternatif model yang terbukti dapat meningkatkan kualitas pembelajaran. Bagi guru, dalam proses pembelajaran diharapkan dapat memanfaatkan media pembelajaran dan model-model pembelajaran degan lebih maksimal. Bagi peneliti Jurnal Riset Madrasah Ibtidaiyah (JURMIA). Vol. 1, No.1 
selanjutnya, dapat dijadikan referensi penelitian selanjutnya jika memiliki permasalahan yang sama.

\section{UCAPAN TERIMAKASIH}

Alhamdulillahirabilalamin, puji syukur penulis panjatkan atas segala rahmat dan karunia-Nya sehingga proses penyusunan artikel ini dapat diselesaikan. Serta penulis ucapkan berterimakasih kepada pihak-pihak yang turut andil mendukung kelancaran dalam penyusunan artikel ini, tak lupa penulis sampaikan terimakasih kepada keluarga besar Sekolah Dasar Negeri Kenokorejo 01 yang telah memberikan izin untuk melaksanakan penelitian.

\section{REFERENSI}

Anggawirya, Erhans. 2011. Microsoft Powerpoint 2010. Jakarta: PT. Ercontara Rajawali. Aqib, Zainal, dkk. 2011. Penelitian Tindakan Kelas untuk Guru SD, SLB, dan TK. Bandung: Yrama Widya

Assegaff, Asrani dan Uep Tatang Sotani. 2016. Upaya Meningkatkan Kemampuan Berfikir Kritis Analitis Melalui Model Problem Basea Learning. Jurnal Pendidikan Manajemen Perkantoran 1 (1). 38-48

Lari, Fateme Samiei. 2014. The Impact of Using Powerpoint Presentations on Students Learning and Motivation in Sacondary school. Islamic Azad Univercity, Iran.

Lee, J., \& Martin, L. 2017. Investigating Students' Perceptions of Motivating Factors of Online Class Discussions. International Review of Research in Open and Distance Learning, 18(5), 148-172. https://doi.org/10.19173/irrodl.v18i5.2883.

Muhammad, Maryam. 2016. Pengaruh Motivasi Dalam Pembelajaran. Lantanida Journal. $4(2)$.

Mutmainah, dkk. 2018. Penggunaan Media Pembelajaran Power Point Untuk Meningkatkan Motivasi Dan Hasil Belajar Siswa SD. Jurnal Teknologi Pendidikan dan Pembelajaran. 5 (2).

Ratna, N. 2013. Hubungan Kecerdasan Emosional dan Kedisiplinan Belajar terhadap Hasil Belajar Biologi Siswa SMA di kota Makasar. Tesis. Program Pascasarjana Universitas Negeri Makasar, Makasar.

Rusman. 2016. Model - Model Pembelajaran. Jakarta: Rajawali Pers.

Sugiyono. 2012. Metode Penelitian Kombinasi (Mixed Menthods). 1. Bandung: Alfabeta

Susanto, A. 2013. Teori belajar dan pembelajaran di SD. Jakarta: Kencana Prenada media group.

Suttrisno, S., Riyanto, Y., \& Subroto, W. T. (2020). Pengaruh Model Value Clarification Technique (Vct) Berbasis Kearifan Lokal Terhadap Motivasi Belajar Dan Hasil Belajar Siswa. NATURALISTIC: Jurnal Kajian Penelitian Pendidikan dan Pembelajaran, 5(1), 718729 
Yanto, Medi. 2013. Jadi Guru yang Jago Penelitian Tindakan Kelas. Yogyakarta: Andi Offset. 